\title{
POLA PERGERAKAN KATAK BATU BERBINTIK HITAM (Staurois gutattus Gunther, 1859) DI GUNUNG POTENG KALIMANTAN BARAT
}

\author{
Mohamad Jakaria ${ }^{1}$, Junardi ${ }^{1}$, Riyandi ${ }^{1}$ \\ ${ }^{1}$ Jurusan Biologi, Fakultas Matematika dan Ilmu Pengetahuan Alam, Universitas Tanjungpura, Pontianak \\ Email korespondensi: jakariamohamad47@gmail.com
}

\begin{abstract}
Movement patterns has been observed in black-spotted rock frog (Staurois gutattus). The aim of this study was to obtain data movement patterns. This research was conducted at Mountain Poteng, West Kalimantan. Data were analized graphically to explain the relationship between the used parameters. There are 20 individual frogs were observed for 24 hours by using a spool track, which consists of 10 males and females. Chi square test result values of alignment grooves conducted on 20 individual frogs were observed during the 24 hours of observation showed that the $\chi^{2}$ count $<\chi^{2}$ table with a value of $\left(\chi^{2}=0,61<3,481, p=0,05\right.$; Chi square test), it shows that the pattern of movement of male and female frogs do not stay away from the starting point of observation.
\end{abstract}

Keywords: Chi square, Mountain Poteng, Staurois gutattus, spool track

\section{PENDAHULUAN}

Sebaran organisme di suatu habitat dipengaruhi oleh pergerakan dari organisme dan perilaku reproduksi (Macfadyen, 1963). Hewan-hewan vertebrata umumnya termasuk Amfibi membatasi pergerakan pada suatu wilayah yang disebut home range atau wilayah jelajah. Home range adalah wilayah yang dijelajahi individu satwa secara teratur untuk memenuhi kebutuhan hidupnya seperti pakan, minum, tempat berlindung, tidur dan kawin (Boughey, 1973). Amfibi dapat melakukan melakukan pergerakan pada lokasi yang berbeda di setiap tahun untuk memenuhi kebutuhan seperti hibernasi, reproduksi dan nutrisi (Stebbins \& Cohen, 1995).

Penelitian tentang pergerakan Amfibi telah banyak dilakukan antara lain oleh Siregar (2013) yang menjelaskan bahwa baik individu jantan maupun betina Rhacophorus margaritifer melakukan pergerakan yang menjauhi titik awal pengamatan. Hasil penelitian ini berbeda dengan penelitian Muliya (2010) yang menujukan katak jantan maupun betina tidak menjauhui titik awal pengamatan. Individu katak baik jantan maupun betina bergerak lebih jauh pada malam hari daripada siang hari. Sholihat (2007) melakukan penelitian pada katak pohon bergaris (Polypedates leucomystax) yang sebagian besar katak jantan pergerakannya tidak menjauhi titik awal pengamatan, sedangkan untuk katak betina ada sebagian yang menjauhi titik awal pengamatan dan sebagian lagi mendekati titik awal pengamatan. Menurut Sholihat (2007) sebagian besar katak jantan bergerak di sekitar sumber air dan tidak jauh dari posisi pertama kali ditemukan. Katak betina pergerakannya lebih luas dan akan mendekati sumber air apabila sudah siap untuk melakukan perkawinan.

Katak batu berbintik hitam (S. gutattus) memiliki distribusi terbatas di Borneo (Inger \& Stuebing, 1997) katak ini juga telah diketahui mendiami habitat di sepanjang aliran sungai yang jernih dan berarus (Malkmus et al., 2002). Katak ini juga mempunyai perilaku reproduksi yang khas berupa tampilan sinyal visual (foot-flagging) (Preininger et al., 2009). Habitat katak ini terus mengalami penurunan akibat pembangunan dan aktivitas manusia lainnya seperti pembukaan lahan untuk perkebunan dan pemukiman.

Penurunan kualitas lingkungan akan berkibat pada kecenderungan populasinya terus mengalami penurunan (IUCN, 2018).

Pembukaan lahan dan pembangunan bendungan dan kolam telah ditemukan di Gunung Poteng Cagar Alam Raya Pasi akan dapat menjadi penyebab penurunan kualitas habitat akibat berkurangnya tingkat kelembaban. Perubahan kondisi habitat tersebut dapat berpengaruh terhadap katak batu 
karena katak ini memiliki kecenderungan untuk memilih habitat yang memiliki kelembaban yang tinggi (Irvin et al., 2003). Katak batu juga banyak memanfaatkan batu dan tumbuhan untuk melakukan aktivitas foot-flagging (Grafe \& Wanger, 2007) sehingga dengan adanya perubahan kondisi habitat dapat berakibat pada perubahan perilaku katak batu berbintik hitam (S. gutattus).

Informasi tentang katak batu berbintik hitam $S$. gutattus di Gunung Poteng, Cagar Alam Raya Pasi saat ini masih terbatas hanya pada keberadaannya. Sementara itu informasi lainnya tentang katak ini masih belum tersedia. Penelitian tentang pola pergerakan dan perilaku berbiak pada $S$. gutattus perlu dilakukan untuk mendapatkan informasi lainnya sehingga diharapkan dapat menjadi data tambahan tentang sifat biologinya.

\section{BAHAN DAN METODE}

\section{Waktu dan Tempat}

Penelitian ini dilakukan selama 4 bulan mulai bulan Januari-April 2019. Pengamatan pola pergerakan katak dilakukan selama 24 jam, mulai pukul 19.00 sampai 19.00 WIB. Lokasi penelitian di Cagar Alam Raya Pasi, Gunung Poteng, Kalimantan Barat.

\section{Deskripsi Lokasi}

Lokasi penelitian berada di sepanjang aliran air yang memiliki lebar 3-4 meter dengan kedalaman 0,5-1 meter, suhu air $25^{\circ} \mathrm{C}$, Suhu udara $27,3^{\circ} \mathrm{C}$, kelembaban $75 \%$ dan aliran air memiliki substrat dasar berupa batu dan pasir dengan arus deras (Hasil Observasi Awal, 2018).

Gunung Poteng secara geografis terletak di antara $0^{\circ} 49^{\prime}-0^{\circ} 51^{\prime}$ Lintang Utara dan $108^{\circ} 59^{\prime}-109^{\circ} 91^{\prime}$ Bujur Timur, Kota Singkawang, Kalimantan Barat (Gambar 1). Kawasan yang merupakan bagian dari Cagar Alam Raya Pasi yang memiliki fungsi penting sebagai kawasan konservasi bagi flora dan fauna yang hidup di dalamnya. Selain itu, kawasan ini juga memiliki fungsi hidrologi dan penghasil cadangan oksigen di kota tersebut (Balai Konservasi Sumber Daya Alam, 2008). Pada Gunung Poteng dijumpai aliran air, kolam dan telah ada upaya mengubah habitat alami dengan membuat bendungan air.

\section{Alat dan Bahan}

Alat dan bahan yang digunakan dalam penelitian ini antara lain: alat tulis, baterai, GPS (Garmin 76CSX), handy camp, kaliper digital (Mitotuyo), kantung plastik, kamera, keping secchi, meteran (100 meter), pH meter (Hana pH-009), tally sheet, timbangan, Thermohigrometer (DC105), stopwatch, senter, spool track dan tali rapia.

\section{Pengumpulan Data Pola Pergerakan Harian Staurois gutattus}

Pengamatan dilakukan pada 20 individu dewasa (10 jantan, 10 betina). Pengamatan dilakukan selama 2 hari, setiap hari diamati sepasang katak jantan dan betina, masing-masing lima pasang setiap satu hari pengamatan. Katak-katak yang diamati ditangkap dengan cara menangkap langsung sepasang katak jantan dan betina yang ditemukan di lokasi penelitian. Katak yang ditangkap terlebih dahulu ditimbang dan diukur panjang tubuh dari ujung moncong sampai anus (Snout Vent Length/SVL) dengan menggunakan kaliper digital. Katak yang telah diukur kemudian dipasangi alat spool track berisi tali (Sholihat, 2007).

Jarak pergerakan individu katak diukur dengan cara mengukur panjang tali yang dibawa oleh masingmasing katak dan diamati setiap tiga jam selama 24 jam. Jejak katak yang terekam dari tali diikuti dan pada setiap titik pengamatan diberi tanda (Sholihat, 2007).

\section{Analisis data}

Data yang didapatkan dianalisis dalam bentuk grafik untuk menjelaskan hubungan antara parameterparameter yang diukur. Jarak pergerakan dari individu $S$. gutattus diperoleh dengan mengukur jarak antar titik-titik yang diambil setiap tiga jam pengamatan. Hasil pengukuran jarak tersebut digunakan untuk memetakan pergerakan katak selama satu hari. Analisis, semua pergerakan $<0,05$ $m$ dianggap sebagai nol karena dengan jarak pergerakan tersebut dapat diartikan sebagai pergerakan yang dilakukan di tempat atau hanya bergesar dari posisi awal (Muliya, 2010). 


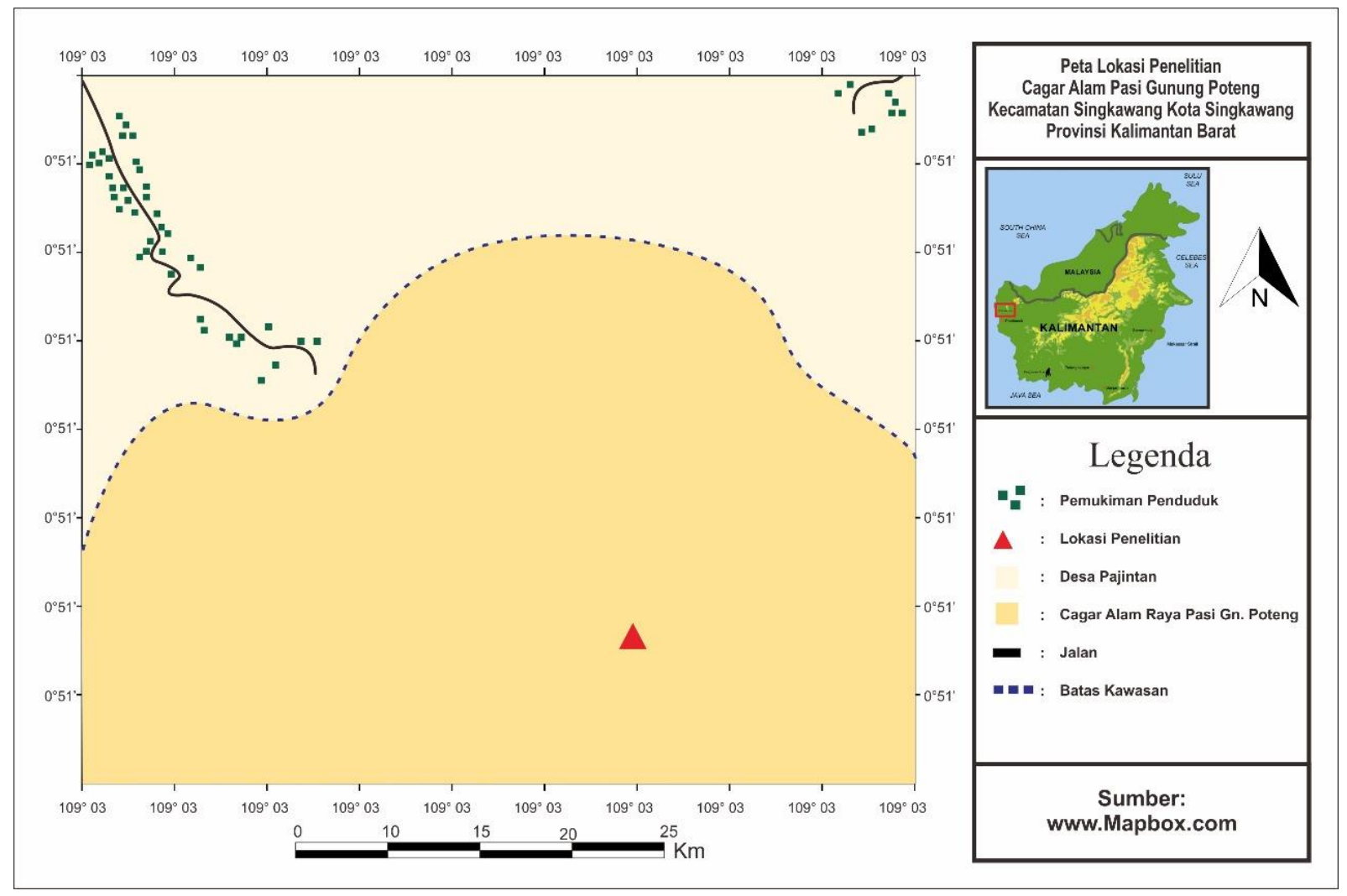

Gambar 1. Peta lokasi penelitian

Pergerakan katak dianalisis secara kuantitatif untuk melihat net displacement dan alur kelurusan dari pergerakan (straightness of the movement trail) (Gambar 2). Net displacement yaitu jarak yang ditempuh selama katak dipasangi alat dan biasanya diukur selama 24 jam (Schwarzkopf \& Alford, 2002). Nilai alur kelurusan diperoleh dengan menghitung rasio dari jarak kumulatif total katak bergerak dengan jarak antar titik awal ke titik akhir pengamatan (Schwarzkopf \& Alford, 2002). Total jarak antara titik awal ke titik akhir yaitu berupa jarak lurus, sedangkan jarak kumulatif total pergerakan yaitu berupa jarak tempuh.

Nilai alur kelurusan digunakan untuk melihat pola pergerakan katak selama 24 jam, apakah bergerak menjauhi titik awal ataukah hanya bergerak di sekitar titik awal saja. Nilai alur kelurusan adalah 01, angka 1 mengindikasikan katak bergerak ke luar dalam pola alur lurus, sementara 0 menunjukan tidak adanya pergeseran (Muliya, 2010).

Nilai alur kelurusan $=\frac{r}{s}$

$\mathrm{r}$ : jarak titik awal ke titik akhir

$\mathrm{s}$ : jarak kumulatif total pergerakan

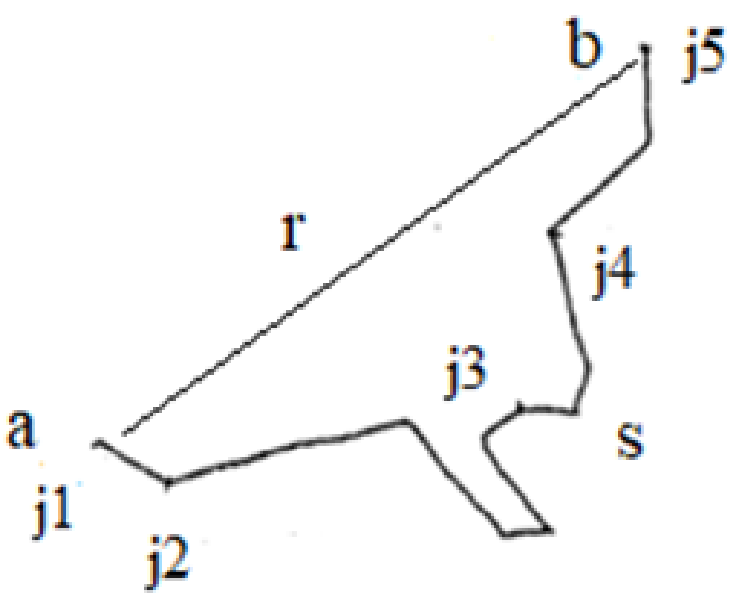

Gambar 2. Pola pergerakan katak: (a) titik awal; (b) titik akhir; (r) jarak titik awal ke titik akhir; (s) jarak kumulatif total pergerakan; (J1) jam 07.30; (J2) jam $10.30=13.30$ = 16.30; (J3) jam 19.30; (J4) $22.30=01.30 ;$ (J5) jam $04.30=07.30$ (Sholihat, 2007).

Uji hipotesis juga dilakukan terhadap nilai alur kelurusan dengan menggunakan metode chi kuadrat (Muliya, 2010). Hipotesis berdasarkan nilai alur kelurusan dengan Ho adalah pola pergerakan jantan dan betina tidak menjauhi titik awal pengamatan sedangkan $\mathrm{H} 1$ adalah pola pergerakan jantan dan betina menjauhi titik awal pengamatan. Rumus $\chi^{2}$ yang digunakan adalah: 


$$
\chi 2 \text { hitung }=\sum_{i=1}^{k} \frac{(O i-E i)^{2}}{E i}
$$

$$
\begin{array}{ccl}
\text { Keterangan } & \chi^{2} & : \text { Chi kuadrat } \\
& \mathrm{E} & \begin{array}{c}
\text { : Frekuensi harapan } \\
\text { nilai alur kelurusan }
\end{array} \\
& \mathrm{O} & \begin{array}{c}
\text { Frekuensi pengamatan } \\
\text { (Fauzy, 2017) }
\end{array}
\end{array}
$$

\section{HASIL DAN PEMBAHASAN}

\section{Hasil}

Katak batu berbintik hitam $S$. gutattus yang digunakan sebagai objek pengamatan pergerakan sebanyak 20 individu. Pergerakannya diamati selama 24 jam dan menggunakan alat spool track yang dipasang pada tubuh katak. Dua puluh individu tersebut terdiri atas sepuluh individu jantan dan sepuluh indsividu betina. Hasil menunjukan bahwa pada siang dan malam hari posisi horizontal terdekat dari badan air untuk katak jantan lebih dekat dibandingkan dengan katak betina (Tabel 1). Rata-rata pergerakan selama tiga jam yang dilakukan katak jantan lebih dekat dibandingkan dengan katak betina pada malam maupun siang hari
(Tabel 1). Pada malam dan siang hari pergerakan maksimum tiga jam lebih jauh terjadi pada katak betina (Tabel 1).

Posisi horizontal katak dari badan air digunakan untuk melihat penyebaran horizontal Amfibi pada suatu habitat sedangkan posisi vertikal Amfibi dari badan air digunakan untuk melihat penyebaran Amfibi berdasarkan ketinggian (apakah menyusup di dalam tanah, diatas pohon, diatas batu atau diatas kayu) (Kusrini, 2009). Hasil menunjukan rata-rata pergerakan katak secara horizontal dan vertikal dari badan air lebih jauh pada siang hari daripada malam hari untuk katak jantan, sedangkan rata rata pergerakan horizontal dan vertikal dari badan air lebih jauh pada malam daripada siang hari untuk katak betina (Tabel 1).

Hasil menunjukan pola pergerakan katak betina 1 Staurois gutattus bergerak lebih jauh jika dibandingkan dengan katak jantan 1, sedangkan di bendungan 2 untuk katak betina 2 pergerakannya lebih jauh jika dibandingkan dengan katak jantan 4 .

Tabel 1. Pergerakan Katak Setiap Tiga Jam Pengamatan

\begin{tabular}{clrr}
\hline Waktu Pengamatan & Pola Pergerakan & Betina $(\mathrm{cm}) \mathrm{n}=10$ & Jantan $(\mathrm{cm}) \mathrm{n}=10$ \\
\hline \multirow{5}{*}{ Malam } & Pergerakan minimum antara tiga jam & 0 & 0 \\
& Pergerakan maksimum antara tiga jam & 1230 & 740 \\
& Pergerakan rata-rata selama tiga jam & 260 & 113 \\
& Posisi horizontal terdekat dari badan air & 22 & 8 \\
& Posisi horizontal terjauh dari badan air & 2520 & 2180 \\
& Rata-rata posisi horizontal dari badan air & 433 & 548 \\
& Posisi vertikal terdekat dari badan air & 20 & 0 \\
& Posisi vertikal terjauh dari badan air & 525 & 483 \\
& Rata-rata posisi vertikal dari badan air & 127 & 134 \\
& Pergerakan minimum antara tiga jam & 0 & 0 \\
& Pergerakan maksimum antara tiga jam & 1812 & 630 \\
& Pergerakan rata-rata selama tiga jam & 227 & 64 \\
& Posisi horizontal terdekat dari badan air & 15 & 0 \\
& Posisi horizontal terjauh dari badan air & 2543 & 2116 \\
& Rata-rata posisi horizontal dari badan air & 266 & 667 \\
& Posisi vertikal terdekat dari badan air & 5 & 0 \\
& Posisi vertikal terjauh dari badan air & 532 & 545 \\
& Rata-rata posisi vertikal dari badan air & 96 & 139 \\
\hline
\end{tabular}

Pergerakan katak jantan 1 di bendungan 1 dan pergerakan pergerakan katak jantan 5 di bendungan 2 yang dilakukan oleh katak Staurois gutattus menunjukan pergerakan yang lebih kecil dibandingkan katak betina. Tetapi tidak selalu pergerakan katak jantan jauh lebih kecil dibandingkan dengan katak betina. Seperti yang ditunjukan pada pengamatan di bendungan 1 terlihat bahwa pergerakan katak jantan 2 lebih banyak dibandingkan katak betina 4 . 
Hasil pengamatan pergerakan, terlihat bahwa terdapat perbedaan antara pergerakan katak jantan dan betina. Hal ini terlihat dari total pergerakan yang dilakukan selama 24 jam dan hasil chi kuadrat hitung yang lebih kecil chi kuadrat tabel $(0<$ 3,481 ), terlihat bahwa katak betina pergerakannya lebih luas dibandingkan dengan katak jantan. Nilai alur kelurusan dihitung untuk menunjukan pergerakan katak menjauhi atau tidak menjauhi titik awal pengamatan. Pola pergerakan katak jantan dan betina tidak menjauhi titik awal pengamatan. $\chi^{2}$ hitung $<\chi^{2}$ tabel dengan nilai $\left(\chi^{2}=0,61<3,481\right.$, $\mathrm{p}=$ 0,05 ; uji chi kuadrat). Meskipun uji chi kuadrat menunjukan bahwa katak jantan dan betina bergerak tidak menjauhi titik awal pengamatan, tetapi terlihat bahwa katak betina memiliki nilai alur kelurusan yang lebih tinggi jika dibandingkan dengan katak jantan (Tabel 2).

Tabel 2. Hasil perhitungan rata-rata jarak tempuh,ratarata jarak dari posisi awal ke akhir dan rata-rata nilai alur kelurusan S. gutattus

\begin{tabular}{ccccc}
\hline Lokasi & Jenis & JT $(\mathrm{m})$ & JO $(\mathrm{m})$ & $\mathrm{NK}(\mathrm{m})$ \\
& kelamin & $\mathrm{n}=5$ & $\mathrm{n}=5$ & $\mathrm{n}=5$ \\
\hline Bendungan 1 & Jantan & 9,56 & 4,01 & 0,47 \\
& Betina & 23,98 & 13,81 & 0,54 \\
Bendungan 2 & Jantan & 6,02 & 3,60 & 0,62 \\
& Betina & 19,09 & 14,52 & 0,80 \\
\hline
\end{tabular}

\section{Pembahasan}

Pergerakan katak setiap tiga jam pengamatan menunjukan bahwa pada siang dan malam hari posisi horizontal terdekat dari badan air untuk katak jantan lebih dekat dibandingkan dengan katak betina, disebabkan aktivitas katak jantan saat pengamatan terlihat ada katak jantan 1 di Bendungan 1 bergerak mendekati badan air pada pukul 19.00, katak tersebut berdiam diri diatas batu yang berada di badan air. Pergerakan rata-rata selama tiga jam yang dilakukan oleh katak jantan lebih dekat dibandingkan dengan katak betina pada malam maupun siang hari, dikarenakan saat pengamatan terdapat katak jantan ditemukan menyusup dalam tanah dan menyusup dalam serasah diduga ini dilakukan untuk berlindung dari predatornya.
Rata-rata pergerakan katak secara horizontal dan vertikal dari badan air lebih jauh pada siang hari daripada malam hari untuk katak jantan, disebabkan banyak katak jantan yang digunakan untuk pengamatan pola pergerakan bergerak menjauhi badan air dan diam diatas batu-batu besar diduga katak tersebut bergerak untuk mencari makan. Pada malam dan siang hari pergerakan maksimum antara tiga jam lebih jauh terjadi pada katak betina, ini dikarenakan pada setiap pengamatan katak betina selalu mengalami pergerakan dan perpindahan dari posisi awal dan ditemukan juga katak betina yang bergerak jauh seperti pada katak betina 1 dan 2 yang terdapat di Bendungan 1. Rata-rata pergerakan secara horizontal dan vertikal dari badan air lebih jauh pada malam hari daripada siang hari untuk katak betina, ini disebabkan pada malam hari aktivitas katak betina meningkat dan biasanya katak bergerak ke posisi terbuka di daerah perairan (Hodgkison \& Hero, 2001). Hal yang sama ditemukan pada pengamatan penelitian bahwa katak betina selalu mengalami perpindahan dari posisi awal baik secara horizontal maupun vertikal.

Pola pergerakan sebagian besar katak betina pergerakannya lebih jauh dibandingkan dengan katak jantan. Sebagai contoh di Bendungan 1, jarak dari awal dan akhir pergerakan selama 24 jam untuk katak betina 1 adalah 28 meter sedangkan katak jantan 1 adalah 8 meter (Gambar 3). Di bendungan 2 untuk katak betina 2 mencapai 16,60 meter dan jantan 4 mencapai 6,89 meter (Gambar 4). Pergerakan katak betina lebih jauh dibandingkan dengan katak jantan, di karenakan katak jantan terikat dengan daerah bersuaranya seperti analisis yang dilakukan Lemckert \& Brassil (2000) pada katak Myophyxes iteratus dari Australia. Bendungan 1, katak jantan 1 di akhir pengamatan mendekati ke posisi dimana pertama kali ditemukan. Di Bendungan 2 untuk katak jantan 5 hanya menetap di liang (lubang tanah) setelah pergerakan pertamanya pada pukul 22.00 (Gambar 5). ini dikarenakan katak tersebut terus masuk ke dalam liang (lubang tanah) dan tidak dapat diamati lagi pada akhir pengamatan. Diduga ada predasi dari ular yang di alami oleh katak tersebut saat didalam liang (lubang tanah). 

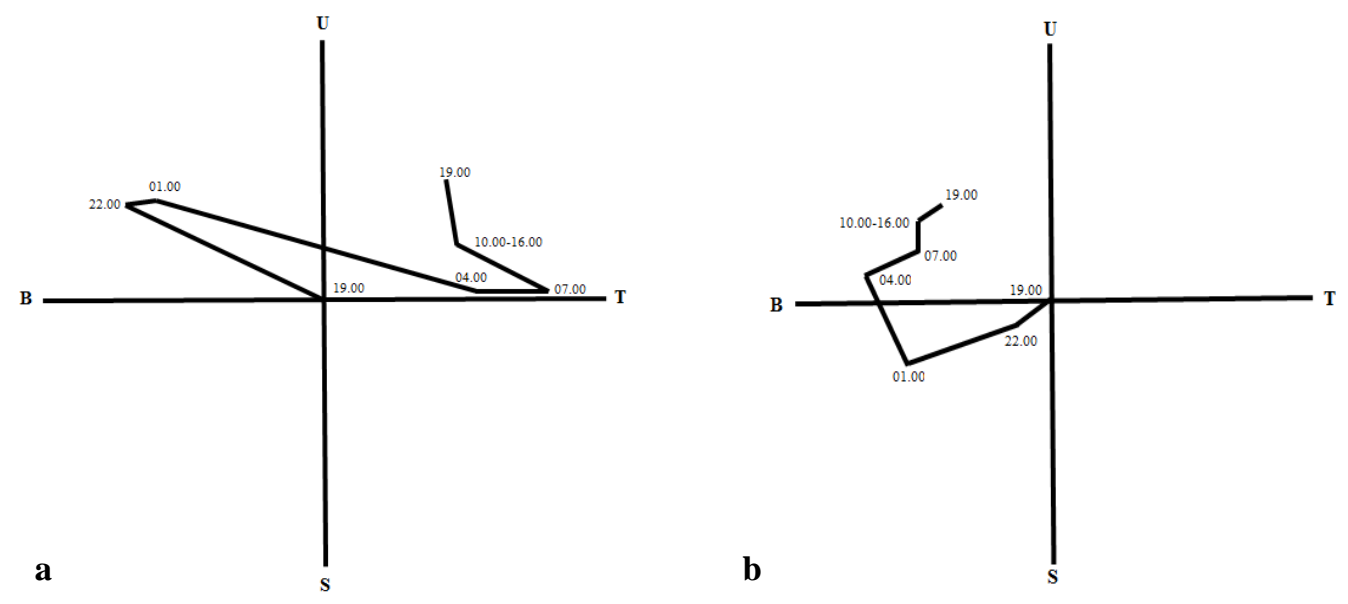

Gambar 3. Pola pergerakan Staurois gutattus betina 1 (a) dan pola pergerakan Staurois gutattus jantan 1 di bendungan 1 (b)


Gambar 4. Pola pergerakan Staurois gutattus betina 2 (a) dan pola pergerakan Staurois gutattus jantan 4 di bendungan 2 (b) 

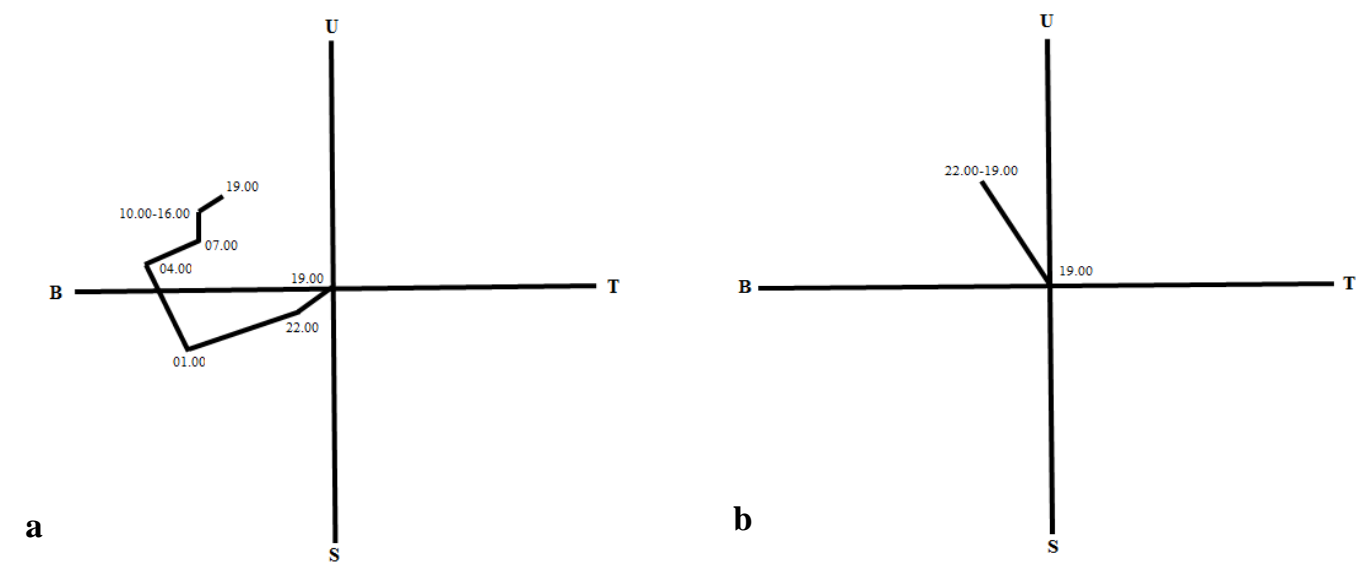

Gambar 5. Pola pergerakan Staurois gutattus jantan 1 di bendungan 1 (a) dan pola pergerakan Staurois gutattus jantan 5 di bendungan 2 (b)
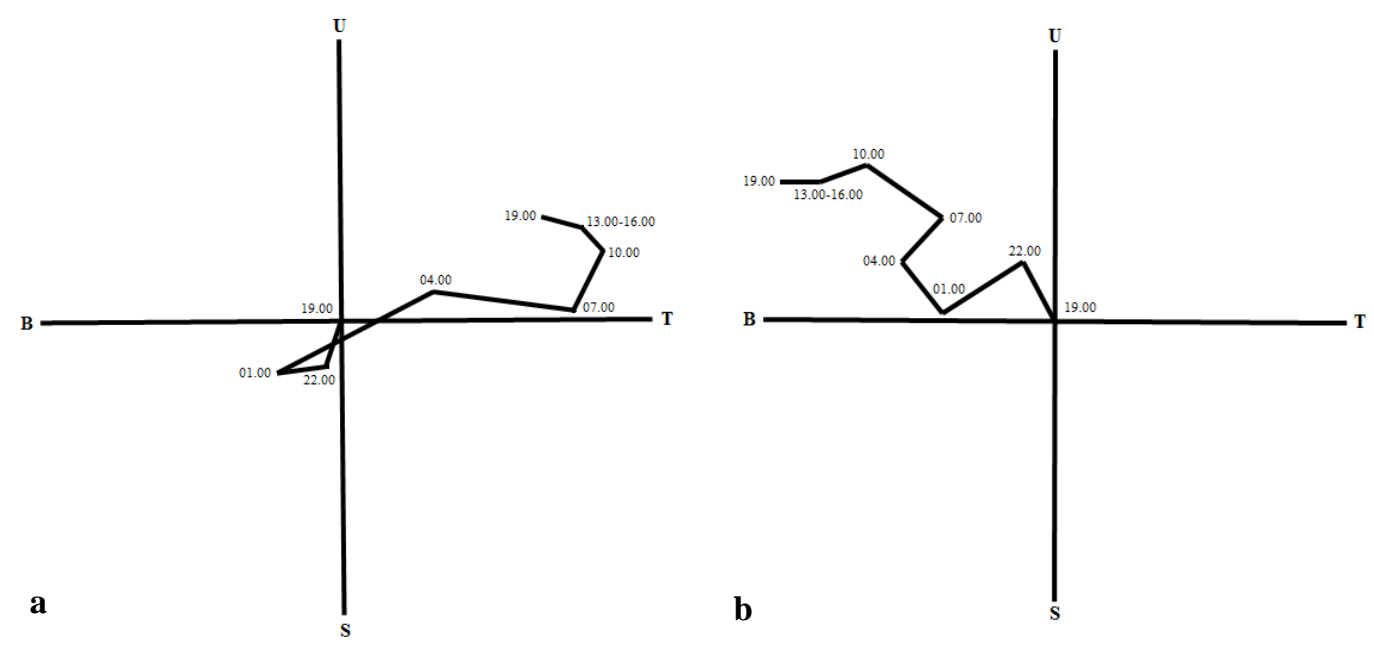

Gambar 6. Pola pergerakan Staurois gutattus jantan 2 di bendungan 1 (a) dan pola pergerakan Staurois gutattus betina 4 di bendungan 2 (b) 
Namun demikian tidak selalu pergerakan katak jantan jauh lebih kecil dibandingkan dengan katak betina. Pengamatan di Bendungan 1 menunjukan pergerakan katak jantan 2 lebih banyak dibandingkan katak betina 4 walaupun terlihat bahwa katak jantan ini cenderung seperti berputarputar di satu lokasi dibandingkan betinanya (jarak posisi akhir dari awal adalah 3,20 meter untuk jantan dan 2,13 meter untuk betina) (Gambar 6). Pergerakan ini berhubungan dengan aktivitas katak tersebut mencari makan. Menurut Dole (1965) banyak dari pergerakan sangat pendek dari tempat awal dan kembali lagi ke posisi awal lagi dapat diartikan sebagai perjalanan mencari makan. Jika terdapat serangga dan mangsa lain yang terlihat oleh katak, katak akan mengikuti mangsa sampai tertangkap atau lepas, kemudian akan mundur ke posisi semula.

Pergerakan dilakukan katak untuk berlindung dari kondisi lingkungan yang tidak mendukung keberadaannya. Menurut Schwarzkof \& Alford (2002) terdapat tiga hal yang potensial dikeluarkan saat katak bergerak antara lain: (1) jumlah energi yang dikeluarkan pada saat ada predator mendekat; (2) digunakan pada saat terjadinya kekeringan yang disebabkan berkurangnya air atau tidak ditemukannya shelter (tempat berlindung) pada saat kekeringan; dan (3) energi yang dikeluarkan pada saat bergerak. Kondisi panas pada siang hari akan membuat katak bergerak mencari tempat yang cocok agar terhindar dari masalah kekeringan. Hasil pengamatan pada siang hari dengan kelembaban berkisar antara $48-70 \%$ katak semakin bergerak masuk ke dalam tempat-tempat yang melindungi tubuhnya dari cahaya matahari. Di lokasi bendungan 1, katak jantan 5 bergerak masuk ke dalam tumpukan serasah dan rerumputan yang ada di lokasi tersebut.

Menurut Duellman \& Trube (1994), arah pergerakan Amfibi dipengaruhi oleh kondisi habitatnya. Pasca perkawinan, sebagian besar pergerakan individu terlihat berada di sekitar lokasi perkawinan untuk memenuhi makanan dan menemukan tempat berlindung dari kekeringan dan pemangsa (Blaustein et al., 1994). Hasil perhitungan nilai alur kelurusan menunjukan sebagian besar dari katak betina memiliki nilai alur kelurusan lebih besar dibandingkan dengan katak jantan, yang berarti pergerakan katak betina lebih menjauhi titik awal pengamatan. Perbedaan jenis kelamin pada katak dinilai memengaruhi nilai alur kelurusan, karena adanya perbedaan sexual dimorfisme yaitu katak betina memiliki ukuran tubuh yang lebih besar jika dibandingkan dengan katak jantan (Kusrini, 2009). Perbedaan ukuran ini berbanding lurus dengan panjang ekstrimitas yang menyebabkan nilai alur kelurusan katak betina lebih jauh dibandingkan dengan katak jantan (Blaustein et al., 1994).

Hasil perhitungan chi kuadrat terhadap total pergerakan katak dengan hasil chi kuadrat hitung lebih kecil dari chi kuadrat tabel, menunjukan bahwa pergerakan antara katak jantan dan katak betina tidak sama selama 24 jam pengamatan, yaitu katak betina lebih luas pergerakannya dibandingkan dengan katak jantan. Hasil perhitungan chi kuadrat nilai alur kelurusan, terlihat bahwa baik katak jantan maupun katak betina pergerakannya tidak menjauhi posisi awal pengamatan. Pergerakan yang tidak menjauhi posisi titik awal pengamatan diduga karena penemuan katak sebagai objek pengamatan tidak jauh dari sumber air. Hal ini diduga terdapat individu katak betina yang akan kawin sehingga pergerakan yang dilakukan tidak jauh dari sumber air. Hasil penelitian menujukan bahwa pergerakan $S$. gutattus tidak berbeda jika dibandingkan dengan penelitian Pope \& Matthews (2001) yang menyebutkan bahwa pergerakan Amfibi berkisar antara 10-100 meter dari tempat perkembangbiakan. Belthoff \& Ritchison (1990) dan Small et al. (1993), juga menyebutkan strategi pergerakan yang ditunjukan vertebrata berubahubah dari sekali perubahan (pergerakan dispersal) atau sebelum satwa mengalami kematangan seksual dan selanjutnya satwa akan bergerak di antara daerah teritori atau wilayah jelajah.

Berdasarkan pola pergerakan terlihat bahwa sebagian besar katak betina pergerakannya lebih jauh daripada katak jantan. Sedangkan berdasarkan Chi kuadrat nilai alur kelurusan bahwa pola pergerakan katak jantan dan betina tidak menjauhi titik awal pengamatan.

\section{DAFTAR PUSTAKA}

Balai Konservasi Sumber Daya Alam, 2008, Informasi Kawasan Konservasi Kalimantan Barat 2008, Pontianak

Belthoff, JR \& Ritchison, G, 1990, Natal dispersal: Gsreenwood, 1980, Revisited, The Condor, vol. 92, no. 3, hal. 803-804

Blaustein, AR, Wake, DB \& Sousa, WP, 1994, Amphibian declines: judging, stability, persistence, and susceptibility of populations to local and global extinctions, Conservation Biology, vol. 8, no. 1, hal. 60-71 
Boughey, AS, 1973, Ecology of Population 2nd Edition, New York: The MacMillan Co

Dole, JW, 1965, Summer movements of adults leopard frog, Rana pipiens Schereber, in Northern Michigan. Ecology, vol. 46, no. 3, hal. 236-225

Duellman, WE \& Trueb, L, 1994, Biology of Amphibians, JHU press

Fauzy, A, 2017, Distribusi Chi Kaudrat, Jurnal MIPA IKIP Malang, vol. 25, No. 1, hal. 103-111

Grafe, TU \& Wanger, TC, 2007, Multimodal Signaling in Male and Female FootFlagging Frog Staurois guttatus (Ranidae): An Alerting Functiion Of Calling, Ethology, vol. 113, no. 8, hal. 772-781

Hodgkison, S \& Hero, JM, 2001, Daily behaviour and microhabitat use of the waterfall frogs, Litoria nannotis in Tully Gorge, Eastern Australia, Journal of Herpetology, vol. 35, no. 1 , hal 116-120

Inger, RF \& Stuebing, RB, 1997, A Field Guide to The Frogs of Borneo, Natural History Publications

Irvin, M, M, Westbrooke \& Gibson, M, 2003, Ecological Effects of Repeated Low Intensity Fire on Reptile Populations in South-Eastern Australia of a Mixed Eucalypt Foothill Forest, Reseach Report no. 65, Victoria: Fire Management Department of Sustainability and Environment

IUCN SSC Amphibian Specialist Group, 2018, Staurois gutattus, The IUCN Red List of Threatened Spescies, diakses 24 September 2018, www.iucnredlist.org

Kusrini, MD, 2009, Pedoman penelitian dan Survei Amfibi di Alam, Fakultas Kehutanan IPB. Bogor

Lemckert, F \& Brassil, T, 2000, Movements and habitat use of the endengered giant barred river for its conservation in timber production forest, Biological Consevation, vol. 96 , no. 2 , hal $177-184$
Macfadyen, A, 1963, Animal Ecology Aims and Methods, Canada: Pitman Publishing

Malkmus, R, Manthey, U, Vogel, GH, Hoffmann, PP \& Kosuch, J, 2002, Amphibians and Reptiles Of Mount Kinabalu (North Borneo), A.R.G, Gantner Verlag Kommanditgesellschaft, Germany

Muliya, N, 2010, Pola Pergerakan Harian dan Penggunaan Habitat Mikro Katak Pohon Jawa (Rhacophorus Margaritifer) di Taman Nasional Gunung Gede Pangrango Jawa Barat, Bogor: Departemen Konservasi Sumberdaya Hutan dan Ekowisata, Fakultas Kehutanan, Institut Pertanian Bogor.

Pope, LK \& Matthews, KR, 2001, Movement of The Green Frog, Rana clamitans, Ecology, vol. 34 , no. 3 , hal. 529-543.

Preininger, D, Boeckle, M, \& Hödl, W, 2009, Communication in noisy environments II: Visual signaling behavior of male footflagging frogs Staurois latopalmatus, Herpetologica, vol. 65, no. 2, hal 166-173

Schwarzkopf, L \& Alford, RA, 2002, Nomadic movement in tropical toads, Oikos. vol. 96, no. 3, hal. 492-506

Sholihat, N, 2007, Pola Pergerakan Harian dan Penggunaan Ruang Katak Pohon Bergaris (Polypedates leucomystax) di Kampus IPB Darmaga, Bogor, Departemen Konservasi Sumberdaya Hutan dan Ekowisata, Fakultas Kehutanan, Institut Pertanian Bogor

Siregar, BA, 2013, Pola Pergerakan Harian Katak Pohon Jawa (Rhacophorus margaritifer) Dengan Menggunakan Metode Radio Tracking Di Taman Nasional Gunung Gede Pangrango Jawa Barat, Departemen Konservasi Sumberdaya Hutan dan Ekowisata, Fakultas Kehutanan, Institut Pertanian Bogor

Small, RJ, Holzwart, JC \& Rusch, CH, 1993, Are ruffed grouse more vulnerable to mortality during dispersal, Ecology, vol. 74, no. 7, hal 2020-2026.

Stebbins, RC \& Cohen NW, 1995, A Natural History of Amphibians, Princeton University Press, New Jersey 